
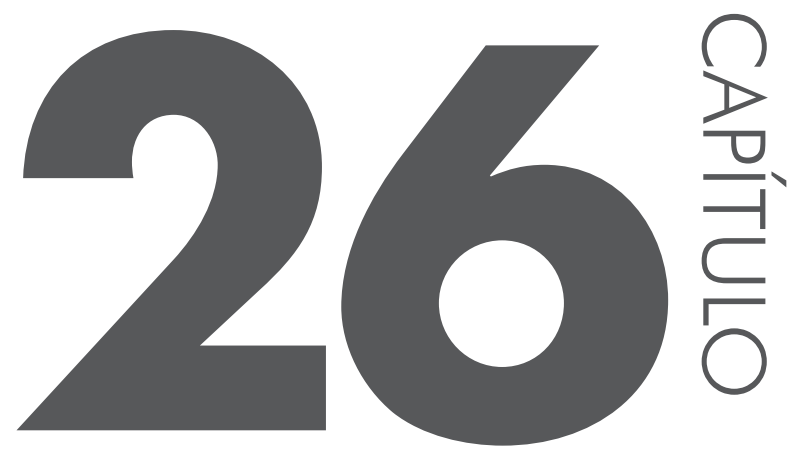

\title{
Diáspora negra em território brasileiro: plantation, quilombo e fronteira econômica
}

\author{
Alejandro Labale \\ Universidade Federal do Piauí
}

A diáspora africana marcou a história de realidades tão díspares quanto diferentes destinos tiveram os navios escravagistas. Os recentes processos de reconhecimento identitário e demarcação de terras de populações rurais negras no Brasil trazem à tona os complexos processos de articulação que essas populações vivenciaram para chegar à atual situação de reivindicação de direitos. Algumas características metodológicas que dão conta de algumas dessas experiências são sistematizadas e comentadas neste texto.

Partindo do princípio de que toda realidade social é relacional, se estabelece como horizonte desejável encontrar continuidades e rupturas nas formas de inserção e articulação das comunidades negras em diferentes contextos, a partir de algumas experiências de primeira mão, em âmbitos rurais do estado de Santa Catarina e Piauí. Colocar em relação essas experiências à luz das políticas públicas de reconhecimento de direitos ajudou a formular a problemática em forma mais ampla e possibilitou a comparação com outras realidades, impactadas por um caminho similar de reconhecimento, identificação e reivindicação de direitos.

A territorialidade negra expressa um contexto carregado pela tensão da relação interétnica; logo, não se trata de simples exclusão, mas de uma articulação conflitante. Tencionamos criticar dessa forma os dualismos explicativos do tipo 
moderno/tradicional, central/marginal ou capitalista/não capitalista. A existência do interstício espacial negro permite a identificação de aspectos que evidenciam cada una das experiências de territorialidade como rede histórica de relações, a partir das quais negros e não negros negociam o espaço social. Muito embora se encontre sempre o grupo negro como minoria política, não se devem negligenciar, na avaliação do processo na sua totalidade, as formas de resistência ativa das quais a territorialidade brinda testemunho espacial e simbólico.

Por outras palavras, entender o processo de formação desses núcleos populacionais, seu status legal de posse da terra e outros problemas associados, depende em grande medida da visão que de si próprios tenham alcançado os grupos para poder entender sua problemática, questão que muitas vezes o mesmo pesquisador ou o gestor público vem a colocar com sua presença - intervenção essa que pode passar a formar parte do processo que marca a constituição do grupo, ao limitá-lo no espaço e diferenciá-lo de outro tipo de experiências sociais.

Concomitantemente, assim como com outras minorias, a positiva construção de identidade abre a um processo paradoxal, no qual o grupo assume como condição prévia o reconhecimento dos estereótipos negativos outorgados pela sociedade envolvente. Ou seja, o processo que deflagra a identidade se realiza sobre o pano de fundo que significou a exclusão e supõe sua assimilação crítica. A constituição do território negro, tal como sugere o balanço desses casos relevados, leva a correlacionar o modelo de desenvolvimento adotado em cada região e as ideologias do embranquecimento social de cada caso. Além de sua necessária consequência, a invisibilização do negro como tal.

Grupos negros territorializaram espaços residuais em termos de apropriação fundiária e intersticiais como correlação de poder, expressando, assim, a complexa relação entre propriedade e posse da terra. Relação essa na qual conseguem coexistir pragmaticamente as mais diversas formas de posse e utilização da terra com o sistema cartorial decorrente da apropriação e regulação fundiária.

O problema da delimitação de territórios negros nos estados de Santa Catarina e Piauí desafia o uso do conceito de "remanescente de quilombo", tanto na implementação de políticas públicas como na sua operacionalização no âmbito da pesquisa acadêmica. O remanescente, tal como definido nos instrumentos constitucionais e sua regulamentação, significa resquício territorial, que por condições históricas se mantém até hoje. Essa "duração" da posse - ou sua expectativa, como direito - não deixa de constituir uma exceção a um dos principais fatores de segregação social: a propriedade da terra.

A intensidade e especialização com as quais os sistemas de "desenvolvimento regional real” incorporaram alguns espaços, assim como deixaram outros intocados, ajudam a entender, mediante a utilização do par ecologia/técnica, porque 
alguns lugares conseguiram permanecer como refúgio, relativamente calmos, à intensidade e violência da apropriação da terra.

Ainda hoje, o registro de propriedade e a regularização de situações de fato (posses) é problema frequente da estrutura fundiária. Logo, incorporação da terra ao sistema de propriedade formal foi realizada em forma seletiva e não exaustiva. A inserção de unidades que combinam formas de posse e uso, com diversas formas de territorialização, permanece como desafio a ser pensado pela pesquisa acadêmica. Em áreas rurais, podem-se reconhecer diferentes tipos de arranjos tecno-ecológicos, valorizando e incorporando, em forma diferencial, a terra disponível; e, ao mesmo tempo, constituem "reservas de espaço possível" para grupos deslocados da lógica do modelo de apropriação territorial predominante.

Como correlato desse modelo técnico e evolutivo, aparece na constituição da sociedade regional certo ideal de cidadania: construção de um brasileiro de matriz europeia como resultado do abstrato processo de progresso material e social. Se nessa construção a ideia de miscigenação é utilizada como forma explicativa, aparece como passado e "sacrifício" em areas do crescimento do novo tipo "brasileiro", mais branco. Ao se reivindicar essa "origem étnica" a sociedade regional coloca no centro de sua justificação a superioridade de "cor" para repartir os créditos da modernização e o progresso. O que está por trás dessa concepção etnocêntrica é a ideia de superioridade evidenciada na capacidade de trabalho, geneticamente concebida, podemos arriscar, parafraseando Giralda Seyferth. Na contrapartida, de forma intercambiável, pode aparecer o caboclo, o índio ou o negro.

É nesse contexto que o grupo negro deve negociar sua territorialidade. Não existe um diacrítico central como o idioma que os identifique e ao que possam remeter um pool específico de valores positivos. Trata-se de uma verdadeira reconstrução étnica, instrumentalizando códigos que viabilizem as relações com a sociedade envolvente, muitas vezes ressignificando estereótipos e categorias acusativas, usando a modo de resistência o que poderíamos chamar de uma estratégia menor, ou seja, a utilização da língua do vencedor para expressar os valores do vencido. 
